\title{
3. Freedom of movement in Europe
}

Freedom of movement for workers shall be secured within the Community. Such Freedom of Movement shall entail the abolition of any discrimination based on nationality between the workers of the Member States as regards employment, remuneration and other conditions of work and employment. (Article 45, Treaty on the Functioning of the European Union)

\section{THE DEVELOPMENT OF FREEDOM OF MOVEMENT IN THE EUROPEAN UNION}

The right to the free movement of persons is one of the four fundamental freedoms that underscore the Internal Market. From the inception of the European Economic Community, it was understood that the creation of a common European market would require that not only goods and capital would travel freely but also people and services. This idea was discussed at length in the 1956 Spaak Report on the General Common Market which gave way to the Treaty of Rome, establishing the EEC (Spaak, 1956). In Chapter 3 (regarding the free movement of labour), the Spaak Report considered the free movement of people in terms of restocking and re-allocating labour across a recovering post-war Europe.

Each State will increase annually the number of workers from other Member States which it will allow to be employed.

a) The basis for the increase will be:

- either the average for the last three years of the number of new workers admitted in each country from other countries of the Community;

- or $1 \%$ of the total number of wage earners for those countries which have in the past employed only a small number of foreign workers.

The rate at which the number of workers is increased can be slower to the extent that the base is large in a particular country: a scale reconciling these two factors should be established.

b) The European Commission will decide on the necessary protection measures 
in order to avoid an inflow of labour which would be dangerous for the standard of living or employment of workers in certain specified industries, without affecting the rights acquired by foreign workers.

c) Access of foreign workers to all jobs will be ensured by the progressive shortening for all occupations of the waiting period of five years applied by the countries of the OEEC before permitting a foreign worker to accept employment.

d) The European Commission will propose to the States measures for the progressive elimination of all discriminatory regulations (legal, administrative, or administrative practices) which, on the basis of nationality, reserve more favourable treatment for nationals than that accorded foreigners with regard to access to an independent profession or the practice of that profession.

This principle will also apply to regulations concerning entry and residence without prejudice to provisions governing public order and safety. (Spaak 1956, p. 19)

The logic of the Spaak Report influenced the design of free movement policy in the coming years. Although the Treaty expressed the founders' determination to 'lay the foundations of an ever closer union among the peoples of Europe', the free movement of people was initially treated as a negative freedom, defined by a concern to remove barriers rather than to promote mobility as a common European right. The wording of Article $3 c$ of the Treaty of Rome (EEC Treaty) illustrates this point in that it specifically calls upon member states to remove 'obstacles' to the free movement of persons and services. At the same time, we note that the Treaty also sowed the seed for further development, since it set out important, though limited, social (e.g. equal pay for equal work for men and women) and legal provisions to enable the then EEC to issue legislation regarding social security.

Over the past 55 years the right to free movement has developed from a negative freedom linked to the labour market to a positive goal associated with the substantive citizenship rights of members of the European Union and the associated rights protected under the European Convention on Human Rights (ECHR). The ECHR, for example, prohibits countries from returning people to situations where they may face torture or inhumane treatment. For the first 30 years the idea of freedom of movement was largely developed in instrumental terms. The Single Market was to be created by means of the liberalization of labour and services that were described as factors of production, not unlike goods. Several commentators maintain that in spite of this logic, the framers of the European Union appreciated the political and socializing aspect that 
resulted from the free movement of people for the purposes of work. More than 25 years ago, Davidson argued that the right to free movement had been interpreted to apply to human as opposed to purely economic concerns (1987, p. 120). This sentiment has since been recorded in much case law, as noted by Siofra O'Leary:

it is equally well known that the case law on the free movement of persons and services is replete with decisions whose reasoning derives as much from a desire to protect and respect the social and human consequences or demands of migration as it does from the aforementioned economic objectives. (O’Leary 2011, p. 505)

Nonetheless, there has been a consistent divide between those who may benefit from the right to free movement. As indicated in the Citizenship Directive, secondary legislation introduced by the Council, European Parliament and European Commission has emphasized the mobility rights of workers and the provision of services that cover an important but restricted sample of intra-European migrants.

One constant of the EEC's interpretation of the Treaty framework has been the restriction of free movement rights on the basis of economic and financial criteria. The most significant instrument that intended to facilitate inter-state travel was aimed at workers, who were seen as building the concept of a united Europe, as spelled out in Regulation 1612/68 and that has since been updated by Regulation 492/2011. Although Regulation 1612/68 recognized the rights of family members, and in effect protected the right to family unity, it could only be enforced through an economically active family member. Free movement was therefore to be restricted to workers defined as those in a subordinate employment relationship and the self-employed, who could demonstrate that they had sufficient resources so as not to be a burden on the host state.

Secondary legislation that aimed to promote the free movement of skilled persons was also drafted with economic criteria in mind. This is evident when one considers the ways in which the recognition of diplomas developed as a policy area by the Council and Commission. Until the introduction of specific legislation that addressed students in 1990, and following the development of a related body of case law, the free movement rights of the highly and semi-skilled could only be exercised if one was in pursuit of a professional job. For the 30 years between 1964 and 1994, the Council and Commission produced over 60 directives in which they interpreted the provisions of the EEC Treaty based on the mutual recognition of diplomas (ex Article 57(1)) to apply to specific professions. These directives applied to a select number of 
individuals who benefited from the Commission's attempts at harmonization across a handful of sectors and were consequently permitted to pursue their professional activities anywhere in the member states, even if their trade was not regulated everywhere. This approach to harmonization proved especially burdensome and was subsequently abandoned in favour of a system that featured the semi-automatic recognition of diplomas that succeeded in promoting the right to free movement of doctors (1993 Doctors' Directive) but saw few other successes.

In the late 1980s the European institutions developed a new system for recognizing qualifications. This system was to set the tone for further efforts to promote the free movement of skilled workers by liberalizing professional services. Directive 89/48/EEC applied to nationals who were fully qualified to practise a regulated profession in the European member states and provided a general system for the recognition of higher education and training of at least a three-year duration at a postsecondary level. Unlike previous directives, it was neither sector- nor profession-specific. This new system introduced the principle of mutual respect that entailed neither blanket recognition nor the presumption of equivalence but rather recognized an obligation to assess 'foreign' qualifications thoroughly. States were nonetheless permitted to introduce additional tests and other requirements such as adaptation periods, most important of which was the requirement stating that one needed to be economically active or seeking to be economically active in a profession. This provision remained a staple of European Union law until 1990, when students were given the right to residence. The introduction of Students' Residence Directive 90/336/EEC therefore marked an important departure where the Council formally recognized that others might also call upon their rights to free movement.

From the late 1990s and most notably between 2004 and 2005, there was a shift in the treatment of mobility rights. New beneficiaries were identified through sweeping provisions that gave greater definition to the idea of European citizenship, included in the Maastricht Treaty (TEU) (1992). Until that point European Union citizenship had largely been considered a nominal complement to national citizenship with few demonstrable benefits. Many who had questioned the significance of European Union citizenship were, however, to find that it eventually grew teeth. On the basis of European Union citizenship family members and others were also to benefit from the right to free movement. 


\section{LEGAL PROVISIONS}

The rights to free movement are set out in the 2010 consolidated version of the TEU signed in Maastricht in 1992 and the Treaty on the Functioning of the European Union (TFEU), formerly known as the EC Treaty, that was signed in Rome in 1957. The main provisions regarding the free movement of persons and the associated rights to social security and welfare are now included in:

- Article 18 TFEU that prohibits discrimination on the basis of nationality;

- Articles 20 and 21 TFEU that set out the rights associated with European Union citizenship, including free movement rights;

- Articles 45-48 TFEU that deal with the free movement of workers and social security coordination;

- Articles 49-53 TFEU that relate to freedom of establishment for self-employed persons.

In addition to the above Treaty provisions, there is an important body of secondary legislation including:

- Regulation (EU) No. 492/2011 of the European Parliament and of the Council of 5 April 2011 on freedom of movement for workers within the Union that replaces Regulation (EEC) No. 1612/68 of the Council of 15 October 1968 on freedom of movement for workers within the Community.

- Directive 2004/38/EC of the European Parliament and European Council on the right of citizens of the Union and their family members to move and reside freely within the territory of the member states (Citizenship Directive).

- Regulation $883 / 2004$ on the coordination of social security systems and its implementing regulation 987/2009.

- Directive 2006/123 on services in the Internal Market (the Services Directive).

- Directive 96/71/EC of the European Parliament and of the Council of 16 December 1996 concerning the posting of workers in the framework of the provision of services (Posting Directive).

- Directive 2005/36/EC on the mutual recognition of professional qualifications.

The member states have also signed the 2000 Charter of Fundamental Rights of the European Union, adding another dimension of rights with 
respect to asylum (Article 18) and prohibition against refoulement (Article 19). As a result of the entry into force of the Treaty of Lisbon, the Charter is now legally binding. EU institutions and member states are bound to comply with the Charter when implementing EU law. This provision is set out in Article 51 of the Charter. In addition to the above, mobility rights have been advanced through the European Court of Justice and feature as part of an important body of case law.

European Union law reflects the tension between the goal of advancing greater mobility and the concern not to endanger national welfare systems. This conflict has seen the Court define greater rights to mobility, reflecting a more integrationist interpretation of EU law. Where the Court had previously found that nationals of a member state may only invoke rights of entry and residence if they had already exercised their freedom of movement to carry out an economic activity in a member state, ${ }^{1}$ in Deborah Lawrie-Blum $v$ Land Baden-Württemberg (C-66/85, 3 July 1986) the Court ruled that restricting free movement to economic integration would be contrary to the broader objective of creating an area in which Community citizens would enjoy freedom of movement. In this ruling the Court signalled an important shift away from the economic logic described above. Labour was not simply to be understood as a commodity but rather as a foundation upon which fundamental rights were anchored.

The imperative of non-discrimination has also been a central feature of both secondary legislation and case law. The free movement Regulations 1612/68 (and now 492/2011) set out several provisions regarding the right to non-discrimination on the basis of nationality and the basis for equal treatment. Article 7(1) of Regulation 1612/68 provides that migrant workers enjoy equal treatment as regards remuneration, stability of employment prospects, promotion and dismissal. In addition to conditions in the workplace, states are required to treat previous periods of comparable employment worked by migrants as professional experience acquired in their state. Article 7(2) further entitles migrants to the same social advantages as national workers. These provisions were upheld in Württembergische Milchverwertung-Südmilch AG v Salvatore Ugliola (C-15/69, 15 October 1969), where the Court confirmed that the free movement of workers requires the abolition of any discrimination based on nationality between workers of the member states, including employment, remuneration and other conditions of work and employment. The Court further ruled in Giovanni Maria Sotgiu v Deutsche Bundespost (C-152/73, 12 February 1974) that all covert forms of discrimination were also prohibited. 
Yet while seeking to reduce the potential for discrimination on the basis of nationality, Regulation 1612/68 restricted the provision of free movement rights on the basis of occupational status in that it was aimed at those who were 'economically active', understood to apply exclusively to workers and self-employed persons. The Court subsequently clarified the meaning of economic activity in D.M. Levin $v$ Staatssecretaris van Justitie (C-53/81, 23 March 1982), where it explained the concepts of 'worker' and 'activities as an employed person' and stated that member states must not interpret these definitions restrictively. The Court, however, informed that the rules on free movement also apply to part-time workers and low paid workers as well. In Deborah Lawrie-Blum v Land Baden-Württemberg (C-66/85, 3 July 1986), the Court further defined a worker as: 'Any person performing for remuneration, work the nature of which is not determined by himself for and under the control of another, regardless of the legal nature of the employment relationship.' This definition is offered in contrast to self-employed people, who do not enjoy a subordinate employment relationship.

In both Levin and Lawrie-Blum, the Court reiterated that work must be 'genuine and effective', a condition which applies to all, including those on temporary contracts and those working fewer hours (e.g. au pairs and trainees). The Court subsequently clarified what was understood by a genuine and effective link. In Gertraud Hartmann $v$ Freistaat Bayern (C-212/05, 18 July 2007), the Court considered the rights of a frontier worker who worked in one state but resided in another. The Court rejected the idea that residence requirements were a means of demonstrating an effective link and hence were not an exclusive basis for determining access to social advantages in the host state. Other factors of integration were also to be assessed. In C-213/03 2007, Wendy Geven v Land Nordrhein-Westfalen [2007] ECR I-06347, the Court ruled that work, which constituted a substantial contribution to the national labour market, should also be regarded as a valid requirement for the status of migrant worker. The Court had recognized in Antonissen (C-292/89) that by restricting free movement rights to those in active employment, job seekers had been excluded. It therefore expanded provisions to include those seeking employment, on condition they provided evidence that they had a genuine chance of being engaged. ${ }^{2}$ The ruling also reiterated the obligation that the host member state may not discriminate and that such migrants should receive the same level of assistance as non-migrants from the national employment office. In Commission $v$ The Netherlands (C68-89, 30 May 1991), the Court also confirmed that nationals of member states have the right to enter the territory of other member states in the exercise of their freedoms, including the right to provide services. 
There are additional distinctions between the rights enjoyed by workers and the self-employed which warrant discussion. While workers are able to access their free movement rights on the basis of work, selfemployed persons must, by contrast, demonstrate that they have sufficient resources and medical coverage in order to reside in the host state. This distinction, although limited to select bands of workers, nonetheless reflects another concern among the member states - namely their fear of 'social dumping' and 'welfare tourism', and their insistence that the self-employed be self-sufficient. This remains an area of tension. The Citizenship Directive later qualified under Article 8(4) that states may not lay down a fixed amount that they regard as 'sufficient resources' but must consider personal situations on a case-by-case basis. The selfemployed still, however, faced several temporal restrictions regarding their rights of establishment and access to services and assistance from the host state, in addition to special transitional restrictions governing EU citizens from new member states (e.g. Croatia).

The Court's interpretation of the Treaty provisions and secondary legislation further deepened the contradiction between the nondiscriminatory provisions and an exclusivity of mobility rights. On the one hand the Court pressed to expand the right to equal treatment - for example, in the case of John O'Flynn v Adjudication Officer (C-237/94, 23 May 1996), where the Court ruled that the principle of freedom of workers also applied to social allowances and made clear that states may only distinguish between nationals and foreign workers if their reasons for doing so are objective and proportionate; otherwise, this could be regarded as a form of indirect discrimination. Similarly, in the Viking ${ }^{3}$ and $\mathrm{Laval}^{4}$ cases, regarding whether collective action could be used to resist what some may view as 'social dumping' within the EU, the Court affirmed the right to strike and ruled that the economic objectives that underpinned the right to free movement needed to be balanced against the objective of improving living and working conditions. On the other hand, while these decisions were of great importance for the development of EU industrial relations, they also highlighted the conditional nature of the ways in which rights may be accessed and that the principal beneficiaries of free movement were still defined according to their economic status.

Other case law has clarified the rights of equal treatment, entry and residence, and return. In the case of Singh (C-370/90, 1992), where a British woman married to an Indian national moved to Germany and then attempted to return to the UK with her husband, the Court ruled that the category of migrant applies even when returning to one's home state. 
Attempts to discourage migrants from returning, in this case by breaking up a family, were considered unlawful.

Students have long benefited from the right to free movement and a guarantee of equal treatment. In Françoise Gravier v City of Liège (C-293/83, 13 February 1985), the Court ruled that member states may not require an EU national from another member state to pay registration fees as a condition of access to vocational training if such fees were not imposed on nationals from the host state. Since then the logic of equal treatment has expanded considerably. In Rudy Grzelczylk and Centre public d'aide sociale d'Ottignies-Louvain-la-Neuve (C-184/99, 20 September 2001), the Court confirmed that member states were not permitted to discriminate against EU citizens who had exercised their free movement rights (in this case, a student). In Grzelczylk, the Court ruled that a student could enjoy the benefit of a social advantage, provided they did not become a burden on the resources of the host state, while recognizing that any potential strain on resources should be balanced against openness and solidarity in cases where one enjoys a temporary right of residence. More recently there have been some notable interpretations of the Treaty provisions by the Court with some radical consequences for students seeking to study in another member state. In Morgan v Bezirksregierung Köln (C-11/06, 2007), concerning a German national who sought a grant to study in the United Kingdom, the Court established a right to export student grants and loans.

The rights of sportspeople to move within the European Union have also received greater attention by the Court. Sport is increasingly a paid activity and the demand for athletes and others in the growing market for sport has generated several cases where the Court has been called upon for clarification. The Court has struck down nationality restrictions in the cases of Walrave ${ }^{5}$ and Gaetano Donà v Maria Mantero (C-13/76, 14 July 1976) as well as in subsequent cases. It has also addressed the issue of transfers between clubs, affirming the right of professional players to move freely in the European Union.

The parallel development of European citizenship further expanded and clarified the free movement rights, including the rights to residence and establishment enjoyed by EU nationals. These rights were decoupled from the economic logic described above. In 1998 in a ground-breaking decision the Court ruled in the case of Maria Martinez Sala v Freistaat Bayern (C-85/96, 12 May 1998) that nationals of a member state can rely on their European citizenship for protection against discrimination on grounds of nationality by another member state. Siofra O'Leary explains the significance of this decision: 
First it exploded the notion that the introduction of Union citizenship was little more than a cosmetic exercise which left essentially unaltered the existing legal framework governing the free movement of persons. Secondly, it decoupled the application of the aforementioned principles of free movement and non-discrimination from the need to exercise an economic activity. Thirdly, and regardless of the Court's protestations to the contrary, Martinez Sala indicated that Union citizenship could have a significant impact on the material scope of application of EU law or, at the very least, on what situations were henceforth to be deemed to be governed by EU law and therefore falling within the material scope of the latter. (O'Leary 2011, p. 500)

The rights of European citizens were detailed in the citizenship provisions of Article 21 TFEU as derived from Article 20 (ex Article 17 TEU) that states that European citizenship is held in addition to national citizenship and is provided by the member states and warrants additional civil and political rights normally associated with the rights of sovereign states, including rights to mobility:

2. Citizens of the Union shall enjoy the rights and be subject to the duties provided for in the Treaties. They shall have, inter alia:

(a) the right to move and reside freely within the territory of the Member States;

(b) the right to vote and to stand as candidates in elections to the European Parliament and in municipal elections in their Member State of residence, under the same conditions as nationals of that State.

Article 21 TFEU that sets out the free movement rights for EU citizens and specifies their rights to move and reside within the Union has been complemented by the Citizenship Directive 2004/38/EC that repealed the existing free movement directives, including those discussed above. It left in place an amended Regulation 1612/68 (and its implementing Directive 1408/71) and enlarged the scope of beneficiaries to include not only citizens of the European Union (nationals of the EU member states) but also their dependants and under certain circumstances other family members.

The Citizenship Directive reiterates and expands upon Treaty provisions, including respect for private and family life, freedom to choose an occupation and the right to engage in work (TEU Articles 6-9). It provides all European Union citizens and their family members the right to enter another member state as well as the right to reside there for up to three months on the basis of a valid ID card or passport, irrespective of 
their employment status. European Union citizens acquire an unconditional right of residence after five years' uninterrupted legal residence. These provisions are set out under Article 7 of the Citizenship Directive:

1. All Union citizens shall have the right of residence on the territory of another Member State for a period of longer than three months if they:

(a) are workers or self-employed persons in the host Member State; or

(b) have sufficient resources for themselves and their family members not to become a burden on the social assistance system of the host Member State during their period of residence and have comprehensive sickness insurance cover in the host Member State; or

(c) - are enrolled at a private or public establishment, accredited or financed by the host Member State on the basis of its legislation or administrative practice, for the principal purpose of following a course of study, including vocational training; and

- have comprehensive sickness insurance cover in the host Member State and assure the relevant national authority, by means of a declaration or by such equivalent means as they may choose, that they have sufficient resources for themselves and their family members not to become a burden on the social assistance system of the host Member State during their period of residence; or

(d) are family members accompanying or joining a Union citizen who satisfies the conditions referred to in points (a), (b) or (c).

It should be noted that the definition of a family member is wide and includes those in registered civil partnerships, where those are legally in force in member states.

The extension of the above rights has been complemented by developments in the European Economic Area (EEA) and neighbouring states, where the same rights have largely been extended to nationals of the EEA, including Iceland and Lichtenstein. Swiss nationals may also benefit from the right to free movement within the European Union as a result of two separate agreements.

In terms of social policy, the Directive clarifies the meaning of solidarity that was included in the TEU provisions concerning labour and industrial-related rights such as social security and health care (TEU Articles 20-26). The Citizenship Directive provides European Union citizens not only with the right to travel to another member state to seek employment but also the right to receive the same benefits from the national employment office as nationals. The Citizenship provisions also permit European Union citizens to benefit from the coordination of social security where previous periods of work, insurance or residence in other countries are aggregated and may still count towards their pensions and other entitlements. Most importantly EU citizens residing in other 
member states may receive social security. These rules cover contributory benefits (such as child benefit), attendance allowance, disability living allowance for carers, and non-contributory benefits such as jobseekers allowance, State Pension Credit and disability living allowance. The Directive also provides an additional source of protection in that it permits citizens to retain the status of worker or self-employed person even after their work is ended.

The notion of equal treatment, reaffirmed in Directive 2004/38, has been extended to family members of EU citizens, including third country nationals who have a right of permanent residence. Family members also have the right to work in the host state and send their children to school in the same way as nationals. The children of migrant workers have the right to educational grants and other assistance, though this is not the case for self-employed people, whose family members may only access these benefits after a five-year period of residence in the host state. The Court has subsequently reaffirmed the right to family unity, most notably in the case of Metock, ${ }^{6}$ where the Court had previously ruled that the condition that third country nationals must have been lawfully resident in the European Union in order to access their free movement rights was incompatible with the aims of the Citizenship Directive. Overruling its previous decision in Akrich that upheld the states' competence to regulate a third country national's first entry into the European Union, the Court found that such barriers to family reunification could undermine the right to free movement of EU nationals. Thus, as a result of its ruling in Metock, the Court has shown that European Union citizenship is not merely an ideological token but an enforceable basis of law.

\section{CONFLICTS AND CONTRADICTIONS}

The idea of the Single Market applies no longer just to workers and self-employed persons but also to people who enjoy various types of economic status. Further qualifications to the principle of freedom of movement have been partially addressed by the substantive development of European citizenship through the Citizenship Directive and Court rulings, but the distinction between economically active and non-active citizens remains a source of division; we note as well a division between older member states (pre-2007) and new entrants that are subject to transitional arrangements. Several categories remain outside the scope of these provisions: non-economically active people (with no family link to an EU economically active citizen) who fail to meet the 
test of self-sufficiency (e.g. the ill, elderly and unemployed); and non-EU nationals who cannot derive rights on the backs of family members.

One glaring point of inequality concerns the restrictions to the mobility rights of European Union citizens from new member states. Both the Treaty of Accession of 2003 and the Treaty of Accession of 2005 include temporal provisions which set out transition periods before workers from the new member states are able to enjoy full rights to freedom of movement. Individual member states may restrict the right to work of EU citizens from the acceding states for up to seven years from the date that their home state joined the European Union. In the case of Bulgaria and Romania, this period expired at the end of December 2013. Croatian citizens of the European Union, however, have been denied the full/free movement rights afforded to other European nationals until 2020 and must apply for work permits in other EU member states. Although migrants who are subject to these transitional arrangements are entitled to equal treatment with national workers, once they are legally employed in another EU member state, the use of such transitional arrangements introduces the spectre of protectionism and the denial of access to key social assistance and services.

Moreover, states are still permitted to treat nationals and European Union citizens differently when they may demonstrate a justified distinction (i.e. any restriction must be objectively justified) and member states' actions must be determined to be in pursuit of a legitimate public interest and also proportionate. This applies to areas which may be considered basic rights by large sections of the European population and include, for example, affordable education and decent housing (Chalmers, Davies and Monti 2010). These areas are a source of potential division. The case of Förster (C-158/07) illustrates this point. Förster was a German national who had been denied study finance because she was economically inactive and had not been a resident in the Netherlands for five years. In this case the Court ruled that the Dutch authorities were permitted to deny her the funding that would have been available to Dutch nationals. This was not a matter of nationality-based discrimination but rather a conclusion that she had not satisfied the criteria for integration - in this case, the residence test. As Chalmers, Davies and Monti write, 'for a foreigner, it takes time or work to integrate, but for a national, it does not' (2010, p. 459).

Yet, there are many other instances where the Treaty framework establishes provisions which enhance the rights of European citizens and create a new basis for differentiation. The cases of Hartmann and Morgan demonstrate that those who seek to exercise their rights to free 
movement may benefit, for example, by the receipt of grants and loans for educational purposes; however, such provisions do not apply to non-migrant citizens. Arguably, in order to benefit from EU law one must be a migrant.

The Commission has also found that the free movement provisions are not sufficient to promote mobility. In spite of the above-mentioned developments in European Union law, it recognizes that the numbers benefiting from the exercise of free movement rights are low by comparison with the inward migration of third country nationals into the European Union. Eurostat records that only 2.3 per cent of EU citizens reside in another member state and that almost two-thirds of migrants come from countries outside the European Union. Despite the progress made there are still legal, administrative and practical obstacles to the exercise of free movement rights. Commenting on the European Year of Workers' Mobility in 2006, the Commission noted that:

in addition to the legal and administrative obstacles on which recent efforts have generally focused (e.g. recognition of qualifications and portability of supplementary pension rights), there are other factors that influence transnational mobility. These include housing issues, language, the employment of spouses and partners, return mechanisms, historical 'barriers' and the recognition of mobility experience, particularly within SMEs. (European Parliament/Legislative Observatory 2010, pp. 2-3)

The above barriers have not, however, deterred significant numbers of third country nationals from migrating to the European Union.

The treatment of non-EU nationals in EU law has been briefly discussed in the context of third country nationals who are in a family relationship with an EU citizen. However, the application of EU law goes considerably further and exposes great divisions on the basis of citizenship. Third country nationals may enjoy a right to enter or reside in the European Union in that they have acquired a particular status (e.g. as the spouse or dependant of a European Union citizen, as a student or as a refugee). These categories are nevertheless both limited and restricted, and many third country nationals seeking to enter the European Union will not enjoy such status. These restrictions are the result of both history and design.

Just as the idea of European Union citizenship was being developed at Maastricht, there was a parallel effort to define a common and restrictive approach to immigration and asylum within the European Union. Such developments took place on the heels of the Schengen agreements of 1985 and 1990. Though outside the European Union, these agreements bound most of the then 15 EU member states (with the exception of the 
United Kingdom and Ireland) by means of an international agreement that allows the abolition of internal border checks and establishes a common external frontier. Schengen also provides a common visa system (currently in effect) as well as the development of a common asylum and immigration policy. In addition to the expansion of Schengen, the European Union member states constructed a common policy of border management, immigration and asylum as established in Articles 77-79 TFEU.

Under Article 77 the TFEU provides that the EU will refrain from controlling entry and carrying out checks on all people crossing the internal borders of the EU and further declares (under Article 78) its ambitions for a common asylum policy:

\section{Article 78}

1. The Union shall develop a common policy on asylum, subsidiary protection and temporary protection with a view to offering appropriate status to any third-country national requiring international protection and ensuring compliance with the principle of non-refoulement. This policy must be in accordance with the Geneva Convention of 28 July 1951 and the Protocol of 31 January 1967 relating to the status of refugees, and other relevant treaties.

The TFEU also provides for the fair treatment of third country nationals residing legally within the member states and seeks to combat illegal migration and human trafficking. These provisions have been included in the Area of Freedom, Security and Justice (AFSJ), a series of policies that have been attached to the TFEU under Article 67.

Chalmers, Davies and Monti (2011) note the contradictions inherent in the AFSJ. They argue that the AFSJ should be thought of as contributing to sustaining a particular way of life for its citizens. In this context the above free movement rights should be considered alongside the development of asylum, immigration and security policies. They write that migration policy is paradoxical, since it both affirms the contributions that migration may make to sustaining the European Union and simultaneously treats migration as a threat to its very security. The risk of removals and denial of rights to non-European nationals who cannot demonstrate that they are lawfully present in the European Union presents a less than harmonious image (Sawyer and Blitz 2011).

As to the treatment of refugees and asylum seekers and the protection of the rights of refugees, subsidiary and humanitarian protection has been extensively documented elsewhere. More relevant to our study, however, is the introduction of Directive 2008/115/EC on Common Standards and 
Procedures in member states for Returning Illegally Staying ThirdCountry Nationals (Returns Directive) that sets a new standard in migration policy within the European Union. The Directive compels member states to issue a return decision and in effect prompt the departure of any third country national staying illegally in its territory, unless the state is prepared to offer authorization for 'compassionate, humanitarian, or other reasons'. In this context illegality does not mean a third country national has broken the law; only that they may have breached the terms of their entry to the member state (e.g. not having a valid document or sufficient means of support). This provision has been used to remove significant numbers of foreigners. Chalmers, Davies and Monti (2010) maintain that both in practice and in law, the Directive does not prohibit states from breaking up families or sending sick and vulnerable people back; it only requires member states to respect the principle of non-refoulement as set out in the 1951 Refugee Convention. Other scholars note that even the prohibition against refoulement has not been upheld (see Blitz 2007).

\section{THE EUROPEAN CONVENTION ON HUMAN RIGHTS}

In addition to the development of European Union law, there is an important body of European human rights law that has been developed through the Council of Europe and in particular the European Convention on Human Rights. Although the two bodies of law developed independently, further to the Lisbon Treaty entering into force on 1 December 2009, the EU has established a legal basis for acceding to the ECHR. The European Union member states have drafted an agreement to accede to the European Convention on Human Rights that will be finalized shortly (see European Commission 2014). Accession of the European Union to the ECHR will strengthen the protection of human rights in Europe by ultimately submitting the EU and its legal acts to the jurisdiction of the European Court of Human Rights (ECtHR). This development is especially significant and builds on a series of political steps that have sought to bring these two bodies of law closer together. The 1997 Treaty of Amsterdam first called for respect for the fundamental rights guaranteed by the ECHR, and the Court of Justice of the European Union has since sought to include principles of the ECHR into European Union law.

The proposed accession of the European Union to the ECHR has great significance for the protection of the rights of migrants. Under Article 1, the ECHR protects all those within the territory of signatory parties, regardless of nationality or citizenship. The Convention speaks of the rights of all people and does not mention foreigners as regards rights to 
migration. The only explicit mention of migration is in Protocol 4, which guarantees the right of freedom of movement within the territory, providing that one is legally present.

Article 2 - freedom of movement

1. Everyone lawfully within the territory of a State shall, within that territory, have the right to liberty of movement and freedom to choose his residence.

2. Everyone shall be free to leave any country, including his own.

3. No restrictions shall be placed on the exercise of these rights other than such as are in accordance with law and are necessary in a democratic society in the interests of national security or public safety, for the maintenance of ordre public, for the prevention of crime, for the protection of health or morals, or for the protection of the rights and freedoms of others.

4. The rights set forth in paragraph 1 may also be subject, in particular areas, to restrictions imposed in accordance with law and justified by the public interest in a democratic society.

In addition to the above protocol, we note that other provisions in the ECHR regarding the prohibition against torture, inhuman or degrading treatment or punishment (Article 3) and the right to respect for private and family life that offer foreign spouses protection from state intrusion are subject to some conditions. ${ }^{7}$

The provisions in ECHR Articles 3 and 8 have been used to develop an important body of case law regarding migrants' rights, above all in cases of expulsion. Two pivotal cases which set the standard for protecting the rights of migrants are the ECtHR decision in the case of Abdulaziz, Cabales \& Balkandali v UK [1985] Ser A. 95 and the 1988 case of Berrehab. In the case of the former, the United Kingdom had introduced legislation that restricted the possibility for settled women to bring foreign husbands to live with them in the UK. Men were not subject to this particular restriction. The ECtHR found this law discriminated on the basis of gender and ruled that it was contrary to the Convention. In the case of Berrehab, where the Dutch government attempted to expel the Moroccan father of a Dutch child who resided with its Dutch mother, the ECtHR ruled that any such action would be a breach of an individual's right to family life.

More recently the ECtHR ruled in the controversial case of the radical cleric Abu Qatada (who had been detained under the UK Anti-terrorism, Crime and Security Act 2001) that the United Kingdom was not permitted to return him to Jordan to face terror charges. ${ }^{8}$ In Othman (Abu Qatada) v the United Kingdom (8139/09), the Strasbourg Court considered whether or not the defendant would receive a fair hearing 
(Art. 6) and also whether or not he would be ill-treated if he were returned to Jordan (Art. 3). Although the Court found that deportation would not constitute a violation of the ECHR, it decided that there was a real risk that evidence used in the trial had been obtained by torture and therefore his removal from the UK to Jordan would violate his human rights to a fair trial. Although the cleric was eventually returned to Jordan, as a result of this decision the British government was forced to engage in an active diplomatic effort with the Jordanian authorities to address the above problem and ensure that upon his return to Jordan the defendant would enjoy a trial that met the standards of evidence as set out by the ECHR.

\section{CONCLUSION}

The above analysis records that while labour has been regularly treated as a factor of production, the notion of European citizenship has been steadily developed since 1992. Migrants who were initially identified as inputs in the creation of an integrated European economy are now considered to be social actors with families and a growing set of rights and entitlements. The right to free movement that had been explicitly elaborated with particular emphasis on economic and financial conditions and was restricted to a proportion of the European population has proved to be a more expansive right.

Arguably the idea of European citizenship that was heralded at Maastricht has been the key catalyst for such change. We note that while the policies regarding the mutual recognition of diplomas were developed over 40 years and have since enjoyed some degree of success, the beneficiaries were primarily workers and selected professionals - a fraction of the European population. The conditions attached to the policies permitting free movement have been partially mitigated by the interpretation of Regulation 492/2011 (formerly 1612/68) that promises to protect the rights of family members under the banner of nondiscrimination, as well as case law and the Citizenship Directive 2004/38.

The role of the Court has overwhelmingly pushed the rights of migrants by clarifying EU law in its rulings and through the expansive development of case law as witnessed in the Lawrie-Blum case regarding part-time workers and the Hartmann case regarding frontier workers. We also note the Court's insistence on equal treatment in matters of immigration (e.g. in Singh) which may further impact the right to family unity and education. The case of Morgan further presents a test of how people will draw upon their rights in a global market for education. The 
focus above all on citizenship that was first highlighted in Martinez Sala and developed through the Citizenship Directive and TFEU now promises greater protection for third country nationals, as evidenced in Metock.

The Charter on Fundamental Rights, by which states are bound when implementing EU law, as well as the Court's efforts to define states' obligations with respect to the European Convention on Human Rights, have elevated the place of migrants' rights in the evolution of the European Union. The anticipated accession by the European Union to the European Convention on Human Rights will signal an even greater advance in human rights protection as the ECHR will have a direct effect on states and thus on the European populations housed within them. To date the decisions of the Strasbourg Court have protected non-nationals against expulsion from EU member states. The accession of the European Union to the European Convention on Human Rights will no doubt raise further questions about the ways in which member states may return third country nationals and to what extent they will go to make this happen.

The development of European human rights law is one further example of the increasingly supranational nature of migration policy in both the European Union and in the Council of Europe system. This supranationalism is more complex within the European Union. The development of a substantive European citizenship and the further elaboration of rights to mobility for EU citizens, their family members and others, concepts of sovereignty and the role of the state as a defender of its internal and external borders need to be revisited.

\section{NOTES}

1. See C-35 and C-36/82, Elestina Esselina Christian Morson v State of the Netherlands and Head of the Plaatselijke Politie within the meaning of the Vreemdelingenwet; Sweradjie Jhanjan $v$ State of the Netherlands (27 October 1982).

2. See C-292/89, The Queen v Immigration Appeal Tribunal, ex parte Gustaff Desiderius Antonissen (26 February 1991).

3. C-438/05, International Transport Workers' Federation and Finnish Seamen's Union v Viking Line ABP and OÜ Viking Line Eesti (11 December 2007).

4. C-341/05, Laval un Partneri Ltd v Svenska Byggnadsarbetareförbundet, Svenska Byggnadsarbetareförbundets avd. 1, Byggettan, Svenska Elektrikerförbundet (18 December 2007).

5. C-36/74, B.N.O. Walrave, L.J.N. Koch v International Cycle Union Association, Koninklijke Nederlandsche Wielren Unie and Federación Española Ciclismo (12 December 1974).

6. Full reference is C-127/08, Blaise Baheten Metock and Others v Minister for Justice, Equality and Law Reform (25 July 2008). 
7. Article 8 provides for protection from state interference unless it is law and is necessary in a democratic society in the interests of national security, public safety or the economic well-being of the country, for the prevention of disorder or crime, for the protection of health or morals, or for the protection of the rights and freedoms of others.

8. Othman (Abu Qatada) v the United Kingdom (Application no. 8139/09), [2012] ECHR 56. 